\title{
PEMANFAATAN BLOG SEBAGAI MEDIA PEMBELAJARAN BERBASIS ICT
}

\author{
Nur Komariah \\ Dosen Manajamen Pendidikan Islam \\ Fakultas Islmu Agama Islam, Universitas Islam Indragiri
}

\begin{abstract}
Abstrak
Blog adalah salah satu media pembelajaran berbasisInformation and Comunication Technology (ICT). Dengan pemanfaatan media blog diharapkan dapat menciptakan pembelajaran yang aktif, kreatif, efektif dan menyenangkan. Pemanfaatan blog sebagai media pembelajaran memiliki keunggulan tersedianya informasi secara luas, cepat, dan tepat, adanya kemudahan dalam proses pembelajaran dan dukungan teknologi untuk memudahkan proses belajarmengajar. Penerapan TIK / ICT juga memiliki keunggulan khasya itu tidak terbatasi oleh tempat dan waktu.
\end{abstract}

Kata Kunci: Media Pembelajaran, Blog, ICT

\section{A. Latar Belakang}

Perkembangan Information and Comunication Technology (ICT) atau Tekonologi Informasi dan Komunikasi (TIK) dalam beberapa dekade terahir berjalan sangat cepat. Satu sisi perkembangan ini menjadi solusi bagi dunia pendidikan baik tingkat SD, SLTP, SLTA maupun Perguruan Tinggi (PT) dalam mengakses berbagai informasi terkait pengembangan perguruan tinggi. Namun disisi lain hal ini tentu menuntut kemampuan guru maupun dosen untuk menguasai pemanfaatan ICT dalam mendukung pelaksanaan kegiatan pembelajaran. 
Pemanfaatan ICT dalam kegiatan belajar dan mengajar dalam beberapa tahun terahir sudah mulai memasyarakat, baik tingkat SD, SLTP, SLTA maupun Perguruan Tinggi, walaupun fokus dan bentuk variasinya berbeda-beda sesuai dengan tingkat keilmuan masingmasing peserta didik. Dengan memanfataakan ICT sebagai media pembelajaran selain memudahkan bagi guru maupun dosen dalam menyiapkan materi pembelajaran, media ICT juga sangat membantu guru atau dosen dalam menciptakan lingkungan pembelajaran yang aktif, kreatif, efektif dan menyenangkan. Selain itu pemanfaatan ICT juga mampu meningkankan motivasi dan memudahkan peserta didik dalam memahami materi yang disampaikan. Oleh karena itu tidak mengeherankan jika pembelajaran dengan pemanfatan media berbasis ICT dinilai lebih efektif dan efisien.

Pemanfaatan ICT dalam kegiatan pembelajaran tidak akan berlangsung optimal manakala tidak ada kesiapan dari pihak-pihak yang terkait dengan penyelenggaraan pendidikan. Salah satu ketidak siapan tersebut adalah terbatasnya anggaran dalam penyediaan media pembelajaran. Selain itu, terbatasnya akses informasi juga di duga menjadi salah satu penghambat penyelenggaraan pendidikan dalam mengembangkan media pembelajaran. Namun, disisi lain tuntutan sebuah kurikulum menuntut untuk menciptakan kegiatan pembelajaran yang aktif, kreatif efektif dan menyenangkan perlu untuk diwujudkan.

Salah satu media pembelajaran berbasis ICT adalah blogatau disebut web log adalah sebuah diary atau catatan-catatan pribadi yang disimpan secara online dan umumnya bersifat terbuka bagi siapa saja yang ingin membacanya. bisa juga berisi kutipan dari sumber lain yang 
sengaja dipublikasikan kembali dalam satu tempat. Blog juga sama dengan situs-situs atau web yang sering Anda temui di internet. Materi dan konten merupakan kebebasan penuh dari sang pembuat blog. tentu saja sangat disarankan lebih ke arah membagi pengetahuan yang bermanfaat. ${ }^{1}$

Blog sebagai media pembelajaran berbasis ICT sangat mudah di terapkan dalam kegiatan pembelajaran selain itu dalam pemanfaatannya tidak terbatas pada ruang dan waktu. Walaupun begitu tidak semua guru ataupun dosen mau memanfaatkan media ini dengan berbagai alasan. Oleh karena itu, dalam kesempatan ini penulis akan mengkaji labih lanjut berkenaan dengan pemanfaatan blog sebagai media pembelajaran berbasis ICT.

\section{B. Pembahasan}

\section{Pengertian Media Pembelajaran Berbasis ICT/Multimedia}

Information and Communication Technologies (ICT) atau Teknologi Informasi dan Komunikasi (TIK) adalah teknologi yang mencakup seluruh peralatan teknis untuk memperoses dan menyampaikan informasi. TIK mencakup dua aspek yaitu teknologi informasi dan komunikasi. Teknologi informasi meliputi segala hal yang berkaitan dengan proses, penggunaan sebagai alat bantu, manipulasi, dan pengelolaan informasi. Sedangkan teknologi komunikasi adalah segala sesuatu yang berkaitan dengan

\footnotetext{
${ }^{1}$ Eko Candra, " Pengertian Blog, Fungsi, dan Kegunaanya," dikutip dari http://www.ekocandra.zone/2011/07/pengertian-blog-fungsi-dan-kegunaannya.html, pada hari Kamis, 3 Februari 2016, Jam 15. 30 WIB.
} 
penggunaan alat bantu untuk memproses dan mentransfer dari satu perangkat ke lainnya. ${ }^{2}$

Teknologi informasi dan komunikasi (TIK), jika dilihat dari pengertian diatas maka dapat dipahami bahwa TIK merupakan gabungan dari teknologi informasi dan komunikasi yang saling bersinergi satu dengan lainnya. TIK atau bisa juga dikatakan sebagai Multimedia (gabungan informasi dan komunikasi), yang sesungguhnya merupakan perkembangan paradigma tentang pendidikan.

Berkaitan dengan statement di atas, Munir menjelaskan teknologi informasi dan komunikasi memiliki keterkaitan yang erat satu dengan lainnya. Teknologi informasi lebih pada sistem pengolahan informasi sedangkan teknologi komunikasi berfungsi untuk pengiriman informasi (information delivery). ${ }^{3}$

Perkembangan media pembelajaran yang mengarah pada media pembelajaran yang berbasis ICT merupakan penjabaran dari paradigma pendidik terkait tentang pembelajaran yang lebih berpusat pada pendidik semata. Menurut hemat penulis, teknologi tradisional yang dikembangkan ketika guru menggunakan model pembelajaran konvensional, cenderung terjadi komunikasi satu arah. Implikasinya, pembelajaran menjadi kaku, monoton dan banyak kebutuhan-kebutuhan belajar peserta didik yang tidak terjamah.

${ }^{2}$ Ariesto Hadi Sutopo, Teknologi Informasi Dan Komunikasi Dalam Pendidikan, (Yogyakarta: Graha Ilmu, 2012), h. 1.

${ }^{3}$ Munir, Kurikulum Berbasis Teknologi Informasi Dan Komunikasi, (Bandung: Alfabeta, 2010), h. 9. 
Hal ini menuntut keprofesionalan seorang pendidik dalam mengajar, karena berpengaruh dalam efektivitas pembelajaran. Profesionalitas pendidik salah satunya aspeknya adalah memiliki kompetensi pedagogik. Lebih rinci lagi, Yudhi menjelaskan bahwa, Dalam melaksanakan kompetensi pedagogik, guru dituntut memilki kemampuan secara metodologis dalam hal perancangan dan pelaksanaan pembelajaran. Termasuk di dalamnya penguasaan dalam penggunaan media pembelajaran. ${ }^{4}$ Sekelumit fenomena merupakan fondasi awal dalam pengembangan media pembelajaran agar lebih berdaya guna dalam proses pembelajaran. Sehingga memungkinkan dikembangkan kearah yang lebih "multi-fungsi", atau lebih dikenal dengan media pembelajaran yang berbasis ICT.

Dari paparan di atas, dapat dipahami bahwa media pembelajaran yang berbasis ICT adalah alat yang digunakan untuk mengolah, mentransfer dan memuat data atau informasi dari perangkat yang satu dengan perangkat yang lainnya. Sehingga proses dalam mengkomunikasikan setiap data atau informasi mudah untuk dipahami dan dicerna dalam proses pembelajaran.

Dilihat dari bentuknya, media pembelajaran dapat dikelompokkan menjadi:

a. Media Visual: media yang mampu menampilkan informasi dalam bentuk yang hanya dapat dilihat atau dibaca, misalnya gambar, foto, grafik, diagram, bagan, poster, kartun, komik, buku, dan lain-lain.

${ }^{4}$ Yudhi Munadi, Media Pembelajaran: Sebuah Pendekatan Baru, (Jakarta: Gaung Persada, 2012), h. 1. 
b. Media Audial: media yang mampu menyajikan informasi dalam bentuk yang hanya dapat didengar, misalnya radio, tape recorder, laboratorium bahasa, player MP3, dll.

c. Projected still media: media yang memerlukan proyektor untuk menampilkan informasi dalam bentuk gambar/tulisan yang tidak bergerak, misalnya transparansi slide, slide Power Point, micro film, dll.

d. Projected motion media: media yang memerlukan proyektor untuk menampilkan informasi dalam bentuk gambar/tulisan yang dapat bergerak, misalnya film, televisi, video (VCD, DVD, VTR), komputer dan sejenisnya.

\section{Hakikat Media Pembelajaran Berbasis ICT/Multimedia}

Pada hakikatnya semua media pembelajaran baik yang berbasis ICT atau tidak merupakan alat yang digunakan oleh pendidik untuk menyampaiakan pesan kepada penerima pesan (peserta didik). Setiap media pembelajaran memiliki dua aspek yaitu aspek pesan yang terkandung dalam media (software) dan aspek perangkat (hardware) yang menjadi wasilah untuk menghantarkan pesan kepada penerima pesan.

Sejalan dengan pembahasan di atas, S. Sadiman berpendapat bahwa media atau bahan adalah perangkat lunak (software) berisi pesan atau informasi pendidikan yang biasanya disajikan dengan mempergunakan peralatan. Peralatan atau perangkat keras 
(hardware) merupakan sarana untuk dapat menampilkan pesan yang terkandung pada media tersebut. ${ }^{5}$

Bersandar pada pendapat di atas, maka media pembelajaran meliputi perangkat keras (hardware) dan perangkat lunak (software).Hardware adalah alat-alat yang dapat mengantarkan pesan seperti overhead projector, radio, televisi, dan sebagainya. Sedangkan software adalah isi program yang mengandung pesan seperti informasi yang terdapat pada transparansi atau buku dan bahan-bahan cetakan lainnya, cerita yang terkandung dalam film atau materi yang disuguhkan dalam bentuk bagan, grafik, diagram, dan lain sebagainya.Media berbasis ICT atau Multimedia, menurut sudut pandang ahli media, sebelum berkembangnya dunia Teknologi Informasi, bahwa multimedia dipandang sebagai suatu pemanfaatan "banyak" media yang digunakan dalam suatu proses interaksi penyampaian pesan dari sumber pesan kepada penerima pesan, salah satunya dalam konteks pembelajaran antara guru dan peserta didik. ${ }^{6}$

Dari pemaparan para ahli diatas dapat dipahami bahwa, pada hakikatnya setiap media pembelajaran yang berbasis ICT/Multimedia atau tidak merupakan alat untuk menyampaikan pesan atau informasi baik berupa kata-kata, gambar, video dan sebagainya.

5 Arief S. Sadiman, dkk. Media Pendidikan. (Jakarta: Rajawali, 2007), h. 19.

6 Deni Darmawan, Teknologi Pembelajaran, (Bandung: PT Remaja Rosdakarya, 2012), h. 31-32. 
Adapun manfaat media dalam kegiatan pembelajaran adalah ${ }^{7}$ Penggunaan media pembelajaran dalam pembelajaran tidak mutlak harus diadakan oleh pengajar. Artinya, jika pengajar dalam proses pembelajarannya tidak menggunakan media pembelajaranpun tidak akan dikatakan gagal, karena yang utama dalam proses pembelajaran adalah peserta didik dapat belajar dengan baik dan mencapai tujuan yang hendak dicapai dan telah dirumuskan sebelumnya. Namun demikian, penggunaan media pembelajaran berbasis TIK, akan mendukung keberhasilan pembelajaran, karena memiliki kelebihan kelebihan sebagai berikut:

a. Dapat memberikan pemahaman yang lebih dalam terhadap materipembelajaran yang sedang dibahas, karena dapat menjelaskan konsep yang sulit atau rumit menjadi mudah atau lebih sederhana.

b. Dapat menjelaskan materi pembelajaran atau obyek yang abstrak (tidak nyata, tidak dapat dilihat langsung) menjadi konkrit (nyata dapat dilihat, dirasakan, atau diraba), seperti menjelaskan peredaran darah dan organ-organ tubuh manusia pada mata pelajaran sains.

c. Membantu pengajar menyajikan materi pembelajaran menjadi lebih mudah dan cepat, sehingga peserta didik pun mudah dipahami, lama diingat dan mudah diungkapkan kembali.

${ }^{7}$ H. Munir, Kurikulum Berbasis TIK, (Bandung: SPS Universitas Pendidikan Indonesia), h. 112-113. 
d. Menarik dan membangkitkan perhatian, minat, motivasi, aktivitas, dan kreativitas belajar peserta didik, serta dapat menghibur peserta didik.

e. Memancing partisipasi peserta didik dalam proses pembelajaran dan memberikan kesan yang mendalam dalam pikiran peserta didik.

f. Materi pembelajaran yang sudah dipelajari dapat diulang kembali (playback). Misalnya menggunakan rekaman video, compact disk (cakram padat), tape recorder atau televisi.

g. Dapat membentuk persamaan pendapat dan persepsi yang benar terhadap suatu obyek, karena disampaikan tidak hanya secara verbal, namun dalam bentuk nyata menggunakan media pembelajaran.

h. Menciptakan lingkungan belajar yang kondusif, sehingga peserta didik dapat berkomunikasi dan berinteraksi dengan lingkungan tempat belajarnya, sehingga memberikan pengalaman nyata dan langsung. Misalnya peserta didik mempelajari tentang jenis-jenis tumbuhan. Mereka dapat langsung melihat, memegang, atau merasakan tumbuhan tersebut.

i. Membentuk sikap peserta didik (aspek afektif), meningkatkan keterampilan (psikomotor).

j. Peserta didik belajar sesuai dengan karakteristiknya, kebutuhan, minat, dan bakatnya, baik belajar secara individual, kelompok, atau klasikal.

k. Menghemat waktu, tenaga, dan biaya 


\section{Macam-macamMedia Pembelajaran Berbasis ICT $^{8}$}

Perkembangan teknologi informasi dan komunikasi seiring dengan perkembangan media pembelajaran berbasis ICT dalam dunia pendidikan. Hal ini menunjukkan bahwa dunia pendidikan memanfaatkan perkembangan Teknologi dengan maksimal mungkin. Dengan pemanfaatan media secara optimal akan tercipta kegiatan pembelajaran yang menyenangkan. Oleh karena itu para pakar mengemukakan macam-macam media pembelajaran berbasi ICT. Macam - macam media ICT atau TIK pada dasarnya semua teknologi yang dapat digunakan untuk menyimpan, mengolah, menampilkan dan menyampaikan informasi dalam proses komunikasi. Secara garis besarnya macam-macam media pembelajaran yakni sebagai berikut:

a. Teknologi komputer

Media pembelajaran berbasis komputer atau bisa disebut pembelajaran berbantuan komputer (computer assisted instructional/ CAI) adalah salah satu media pembelajaran yang sangat menarik dan mampu meningkatkan motivasi belajar peserta didik. Penggunaan komputer sebagai media pembelajaran interaktif dapat diwujudkan dalam berbagai bentuk, diantaranya program computer-assisted learning (CAL), konferensi komputer, surat elektronik atau elektronik mail (email), dan komputer multimedia yang kemudian disebut

${ }^{8}$ Nurlaela, "Pengembangan Media Pembelajaran Berbasis ICT," dikutip dari http://nenenggeulis.blogspot.co.id/2015/05/pengembangan-media-pembelajaran. html, pada hari Kamis, 3 Februari 2016, 13.00 WIB. 
multimedia pembelajaran interaktif. Pembelajaran melalui CAI ini, bersifat offline, sehingga dalam penggunaannya tidak tergantung pada adanya akses ke internet.

Program pembelajaran berbantuan komputer ini memanfaatkan seluruh kemampuan komputer, terdiri dari gabungan hampir seluruh media, yaitu: teks, grafis, gambar, photo, audio, video, dan animasi. Seluruh media tersebut secara konvergen akan saling mendukung dan melebur menjadi satu media yang luar biasa kemampuannya. Salah satu keunggulan media komputer ini yang tidak dimiliki oleh berbagai media lain, ialah kemampuannya untuk menfasilitasi interaktifitas peserta didik dengan sumber belajar (conten) yang ada pada komputer (man and machine interactivity). ${ }^{9}$

b. Teknologi multimedia

Media pembelajaran yang termasuk ke dalam teknologi multimedia adalah kamera digital, kamera video, player suara, player video, dll. Multimedia sering diartikan sebagai gabungan dari banyak media atau setidak-tidaknya terdiri lebih dari satu media. Multimedia dapat diartikan sebagai komputer yang dilengkapi dengan $\mathrm{CD}$ player, sound card, speaker dengan kemampuan memproses gambar gerak, audio, dan grafis dalam resolusi yang tinggi. ${ }^{10}$

c. Teknologi Telekomunikasi

${ }^{9}$ Bambang Warsita, Tekhnologi Pembelajaran, (Jakarta: PT. Rineka Cipta, 2008), h. 137-138.

${ }^{10}$ Sutopo, Teknologi...., h.103. 
Yang termasuk media telekomunikasi adalah telepon seluler, dan faximile. Teknologi komunikasi ini sekarang berkembang semakin pesat. Kini tidak hanya dalam bentuk telepon seluler dan faximile saja namun bermacam-macam, seperti Handphone, e-mail, facebook, twitter, Blogger dan lain sebagainya. Namun seiring perkembangan yang semakin pesat, teknologi komunikasi dituntut agar mampu memberikan manfaat yang banyak terhadap dunia pendidikan. ${ }^{11}$

d. Teknologi jaringan komputer

Teknologi ini terdiri dari perangkat keras seperti LAN, internet, wifi, dan lain-lain. Selain itu juga terdiri dari perangkat lunak pendukungnya atau aplikasi jaringan seperti WEB, e-mail, html, java, php, aplikasi basis data dan lain-lain.

Salah satu bentuk pemanfaatan teknologi informasi untuk pembelajaran adalah pengembangan e-dukasi.net yang berbasis internet. E-dukasi.net adalah portal pendidikan yang menyediakan bahan belajar, fasilitas komunikasi, dan interaksi antar komunitas pendidikan. Situs atau portal pembelajaran yang dikembangkan ini dilengkapi dengan fasilitas-fasilitas penyediaan bahan belajar yang meliputi seluruh mata pelajaran untuk seluruh jenjang dan jalur pendidikan, bimbingan belajar, bimbingan dan penyuluhan atau konsultasi, tutorial, remidial, email, forum diskusi, mailing list, dll.

\footnotetext{
${ }^{11}$ Furqan, "Pemanfaatan Media berbasis ICT Terhadap Pembelajaran Sekolah," dikutip dari http://furqanwera.blogspot.com/2012/12/pemanfaatan-mediaberbasis-ict-terhadap.html, pada hari Selasa, 12 Mei 2013, jam 13.00 WIB.
} 
Dengan adanya teknologi internet ini sistem penyampaian dan komunikasi atau (delivery system and comunication) antara peserta didik dan guru, guru dengan guru atau peserta didik dengan peserta didik lain, dan peserrta didik dengan sumber belajar dapat dilakukan dengan berbagai bentuk dan cara, baik secara bersamaan (syncronous) maupun tidak (asyncronuos). ${ }^{12}$

\section{ICT sebagai Alat Bantu (Media) Pembelajaran}

Pendidikan berbasis ICT telah lama dimulai sejak tahun 1960an dengan pendidikan berbasisb komputer. Seiring dengan perkembangan teori belajar, semula pemanfaatan komputer dalam pembelajaran menggunakan pendekatan teori behaviorisme. Komputer lebih banyak digunakan untuk melakukan drill and practice. Perkembangan selanjutnya dipengaruhi oleh teori belajar konstruktivisme, komputer dimanfaatkan untuk membantu siswa menemukan dan merumuskan pengetahuannya melalui interaksi dan eksplorasi sumber-sumber belajar berbasis ICT. Selain itu, pemanfaatan ICT dalam pembelajaran juga mendukung teori socioconstructivism, yakni siswa memperoleh pengalaman belajar secara bersama-sama dengan siswa lain atau melalui interaksi dengan para pakar dengan media komunikasi berbasis ICT. Perkembangan terkini adalah pemanfaatan ICT secara terpadu di dalam pembelajaran yang memadukan berbagai keterampilan dan fungsi ICT di dalam proses belajar mengajar.

${ }^{12}$ Rusman,dkk., Pembelajaran Berbasis TIK, (Jakarta: PT.Raja Grafindo Persada, 2012), h. 338. 
Penggunaan ICT sebagai media pembelajaran dapat berbentuk file slide Power Point, gambar, animasi, video, audio, program CAI (computer aided instruction), program simulasi, dan lain-lain. Penggunaan media berbasis ICT memberikan beberapa keuntungan, antara lain

a. Memvisualisasikan konsep-konsep abstrak,

b. Mempermudah memahami materi-materi yang sulit,

c. Mensimulasikan proses yang sulit dilakukan secara manual

d. menampilkan materi pembelajaran dalam berbagai format (multimedia) sehingga menjadi lebih menarik, dan terbaru (up to date) dari berbagai sumber,

e. memungkinkan terjadinya interaksi antara pebelajar dan materi pembelajaran,

f. mengakomodir perbedaan kecepatan dan gaya belajar siswa,

g. mengatasi keterbatasan ruang, waktu, dan tenaga,

h. mendukung perubahan peran guru ke arah yang positif sebagai fasilitator dan mediator, dari posisi semula sebagai satusatunya sumber pengetahuan,

i. meningkatkan keterampilan individu penggunanya.

Penggunaan media harus didasarkan pada pertimbangan bahwa media tersebut dapat memfasilitasi terjadinya proses belajar atau meningkatkan pemahaman materi pembelajran. 


\section{Teknik Pengolahan Data Dan Informasi Menggunakan Media}

\section{Pembelajaran Berbasis ICT/Multimedia}

a. Data dan Informasi

Setiap media pembelajaran membawa pesan yang berbeda-beda, tergantung dari jenis dan macam medianya. Dalam media memiliki dua aspek selain software dan hardwarenya yaitu aspek data dan informasi. Aspek data adalah pesanpesan yang terkandung dalam media yang belum diproses menjadi sebuah informasi, dan belum siap untuk dikomunikasikan kepada peserta didik dalam proses pembelajaran. Sedangkan informasi adalah data-data atau pesan-pesan yang sudah diolah menjadi sebuah informasi yang siap untuk dikomunikasi kepada peserta didik dalam proses pembelajaran.

Dalam hal ini, Hadi Sutopo menegaskan, data adalah fakta berupa teks, angka, audio, dan video merupakan kumpulan dari sesuatu yang belum diproses. Informasi adalah hasil pemrosesan data yang telah diolah dengan komputer dan bermanfaat bagi penggunanya. ${ }^{13}$ Dan ketika hal ini diterapkan dalam proses pendidikan, maka mampu membawa peserta didik dalam proses pembelajaran yang menyenangkan, membangun suasana pembelajaran yang kondusif dan mampu memenuhi kebutuhan belajar peserta didik.

b. Siklus Pemrosesan Informasi

${ }^{13}$ Ariesto Hadi Sutopo, Teknologi Informasi Dan Komunikasi Dalam Pendidikan, (Yogyakarta: Graha Ilmu, 2012), h. 32. 
Data dan informasi merupakan hal yang paling substantif dalam suatu media untuk diproses agar mengandung makna yang sesuai dengan makna yang ingin disampaikan kaitannya dalam proses pembelajaran. Data yang diperoses menjadi sebuah informasi. Dan informasi yang diolah kemudian diolah kembali dengan informasi-informasi lainnya agar mudah dikomunikasikan.

Data yang masuk sebagai input diolah menjadi informasi (output). Pemakai kemudian menerima informasi tersebut sebagai landasan pembuatan suatu keputusan dan digunkan sebagai data baru dalam proses lain. Atau dalam makna lain, informasi yang sudah diolah sebelumnya di olah lagi dengan informasi atau data-data yang masih mentah sehingga memilki makna yang kompleks. Data baru tersebut selanjutnya menjadi input pada proses berikutnya, begitu seterusnya sehingga membentuk siklus informasi (information cycle).

Siklus informasi merupakan rangkaian yang terdiri dari input, proses, dan output, serta dilengkapi dengan media penyimpanan untuk menyimpan informasi yang dihasilkan. Selain itu, komunikasi menjadi elemen penting dalam siklus pemrosesan informasi. Dengan media komunikasi, data dan informsi dapat dikirimkan ke tempat lain melalui jaringan komputer. Dan untuk lebih jelasnya siklus pemrosesan suatu data dan informasi bisa di lihat pada gambar di bawah ini. ${ }^{14}$

${ }^{14}$ Sutopo, Teknologi...., h. 33-34. 


\section{Siklus Pemrosesan di komputer}

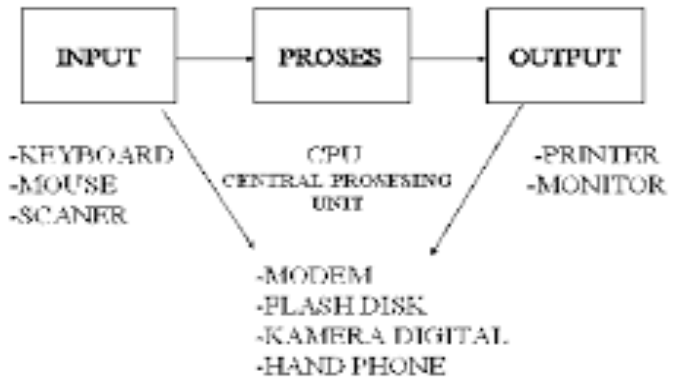

\section{Penggunaan Media Pembelajaran Berbasis \\ ICT/Multimedia}

Asumsi dasar dalam penggunaan media pembelajaran adalah agar dalam proses pembelajaran berlangsung dengan baik dan menarik. Media pembelajaran yang berbasis ICT/Multimedia atau tidak pada dasarnya adalah alat yang digunakan untuk menyalurkan pesan kepada penerima pesan. Multimedia misalnya, ketika digunakan dalam proses pembelajaran memadukan atau menggabungkan beberapa jenis media agar pesan yang disampaiakan lebih bermakna kepada peserta didik.

Richard dengan penjelasannya yang rinci mengatakan, multimedia sebagai prresentasi materi dengan menggunakan katakata sekaligus gambar-gambar. 'kata' di sini adalah materinya disajikan dalam verbal form atau bentuk verbal, misalnya menggunakan teks kata-kata yang tercetak atau terucapkan. Yang dimaksud dengan 'gambar' adalah materinya disajikan dalam fictorial form atau bentuk gambar. Hal ini bisa dalam bentuk 
menggunakan grafik statik (termasuk: ilustrsi, grafik, foto dan peta). Dalam buku teks, kata-kata bisa disajikan sebagai teks cetak dan gambar bisa disajikan sebagai ilustrasi atau bentuk-bentuk grafik lainnya. ${ }^{15}$

Penggunaan media berbasis ICT atau Multimedia membawa pengaruh-pengaruh psikologis bagi peserta didik dalam proses pembelajarannya. Karena semakin banyak indera yang terjamah, maka semakin banyak pula cara peserta didik dalam menerima, mengolah dan memaknai setiap pesan yang disampaiakan oleh pendidik ketika menggunakan media pembelajaran yang berbasis ICT/Multimedia.

Penggunaan media berbasis ICT/Multimedia akan berjalan efektif dan akan mengarah pada pembelajaran yang berpusat pada kegiatan peserta didik (student/ learned centred learing), yaitu dengan: ${ }^{16}$

a. Mengembangkan kemampuan peserta didik untuk memecahkan permasalahan dalam kehidupan nyata (kontekstual), sehingga pendidikan menjadi relevan dan responsif terhadap tuntutan kehidupan nyata sehari-hari. Implikasinya kurikulum menjadi lebih menarik dan dapat merangsang minat atau motivasi peserta didik, karena dapat langsung dengan mudah menerapkan pengetahuannya dalam kehidupan nyata sehari-hari.

b. Menumbuhkan pemikiran reflektif

${ }^{15}$ Richard E. Mayer, Multimedia Learning: Prinsip-Prinsip Dan Aplikasinya, terj. Teguh Wahyu Utomo, (Yogyakarta: Pustaka Pelajar, 2009), h. 3.

${ }^{16}$ Munir, Kurikulum...., h. 175. 
c. Membantu perkembangan dan keterlibatan aktif dari peserta didik dalam proses belajar.Sehingga dapat dikatakan bahwa, penggunaan media pembelajaran berbasis ICT/multimedia lebih kepada mengkongkritkan pengalaman belajar peserta didik agar lebih dipahami dan dimaknai dengan lebih optimal. Selain itu, proses pembelajaran akan bisa mengurangi keabstrakan sebuah materi karena didukung oleh media pembelajaran yang berbasis ICT/Multimedia.

Media pembelajaran berbasis ICT/Multimedia memiliki manfaat yang sangat berpengaruh dalam proses pembelajaran. Jika ditilik secara seksama media pembelajaran berbasis ICT memiliki dua manfaat dilihat dari penggunaannya. Pertama, manfaat dilihat dari sisi pendidik sebagai pengguna dari media. Kedua, manfaat dari sisi peserta didik sebagai penerima pesan yang disampaiakan oleh pendidik.

Mengintegrasikan TIK/ Multimedia ke dalam pembelajaran antara lain untuk meningkatkan kompetensi pengajar dalam mengajar dan meningkatkan mutu belajar peserta didik. TIK yang sifatnya inovatif dapat meningkatkan apa yang sedang dilakukan sekarang serta apa yang belum kita lakukan tetapi akan dapat dilakukan ketika kita mulai menggunakan teknologi informasi komunikasi. ${ }^{17}$

${ }^{17}$ Munir, Kurikulum...., h. 176. 
Sudjana dan Rivai secara lebih rinci mengemukakan beberapa manfaat media pengajaran dalam proses belajar mengajar antara lain: ${ }^{18}$

a. Pengajaran akan lebih menarik perhatian siswa sehingga dapat menumbuhkan motivasi belajar

b. Bahan pengajaran akan lebih jelas maknanya sehingga dapat lebih dipahami oleh para siswa, dan memungkinkan siswa menguasai tujuan pengajaran lebih baik

c. Metode pengajaran akan lebih bervariasi, tidak semata-mata komunikasi verbal melalui penuturan kata-kata oleh guru, sehingga siswa tidak bosan dan guru tidak kehabisan tenaga, apalagi bila guru mengajar untuk setiap jam pelajaran

d. Siswa lebih banyak melakukan kegiatan belajar, sebab tidak hanya mendengarkan uraian guru, tetapi juga aktivitas lain seperti mengamati, melakukan, mendemontrasikan dan lain-lain.

Dapat dipahami bahwa, intraksi yang terjadi dalam proses pembelajaran, meteri ajar yang disampaikan guru tidak sepenuh bisa dicerna dengan baik, karena setiap indra yang menerima pesan memilki keterbatasan. Untuk itu media pengajaran memilki peran yang sangat strategis untuk menyalurkan pesan baik melalui indra pendengar, penglihatan maupun kedua-duanya.

\section{Pengertian Blog dan Langkah-langkah Membuat Blog}

Media blog ini pertama kali dipopulerkan oleh Blogger.com, yang dimiliki oleh Pyra Labs sebelum pada akhirnya diakuisisi oleh

\footnotetext{
${ }^{18}$ Nana Sudjana dan Ahmad Rivai. Media Pengajaran, (Bandung: Sinar Baru Algensindo, 2010), h. 2.
} 
pihak Google pada sekitar akhir tahun 2002. Semenjak itu, banyak terdapat aplikasi-aplikasi yang bersifat sumber terbuka (open source) yang diperuntukkan kepada perkembangan para penulis blog (blogger) tersebut.

Blog merupakan singkatan dari "Web Log" adalah sebuah aplikasi web yang berupa tulisan-tulisan ataupun gambar yang biasa disebut dengan sebuah posting atau postingan dalam sebuah halaman website umum seperti blog. Tulisan-tulisan ini seringkali dimuat dalam urut terbalik biasanya isi terbaru dahulu baru kemudian diikuti isi yang lebih lama, meskipun tidak selamanya seperti ini. Situs web seperti blog ini biasanya dapat diakses oleh semua pengguna Internet sesuai dengan topik atau tujuan yang sedang dicari oleh pengunjung atau visitor darisearch engine.Salah satu penyedia blog gratis yang cukup populer saat ini adalah blogspot atau blogger, dimana ketika mendaftar adalah melalui situs blogger.com namun nama domain yang akan anda dapatkan adalah sub domain dari blogspot, contoh : contohsaja.blogspot.com. adapunlangkah-langkah membuat blog adalah sebagai berikut:

a. Salah satu syarat yang harus dipenuhi dalam membuat blog adalah memiliki alamat email yang masih aktif atau di gunakan. Jika belum mempunyai alamat email, silahkan daftar terlebih dahulu di gmail karena blogger adalah salah satu layanan dari Google maka ketika mendaftar ke blogger sebaiknya gunakan email gmail.

b. Kunjungi situs http://www.blogger.com 
c. Setelah halaman pendaftaran terbuka, alihkan perhatian ke sebelah kanan atas, ubah bahasa ke Indonesia agar lebih mudah dipahami. Silahkan langsung login dengan menggunakan username serta password gmail anda ( akun email anda bisa untuk login ke blogger).

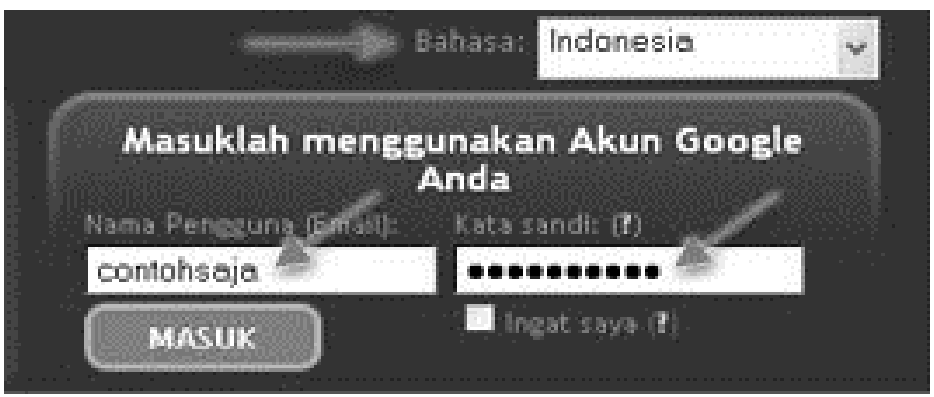

d. Klik tombol bertuliskan CIPTAKAN BLOG ANDA.

ang dari blog mana pun, buat satu mulai tulis entri!

\section{CIPTAKAN BLOE ANDA}

e. Isilah nama judul blog serta alamat blog yang di inginkan. Ingat! dalam membuat alamat blog harus benar-benar serius karena itu permanen tidak dapat digantikan lagi (kecuali nanti ganti dengan custom domain). Jika alamat yang diinginkan ternyata tidak bisa digunakan, masukkan kembali alamat lain yang masih tersedia. Jika alamat blog yang diinginkan masih tersedia, silahkan klik anak panah bertuliskan LANJUTKAN. 


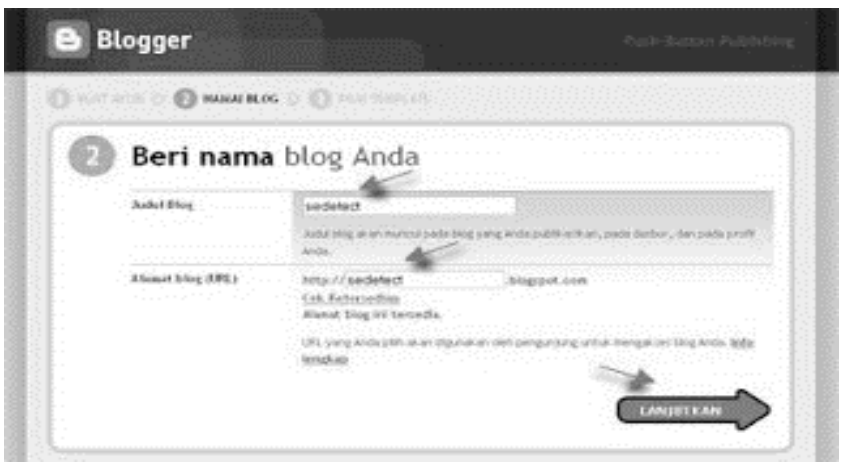

f. Silahkan pilih template yang anda sukai (template ini nanti bisa diubah lagi kapan saja anda mau), kemudian klik LANJUTKAN.

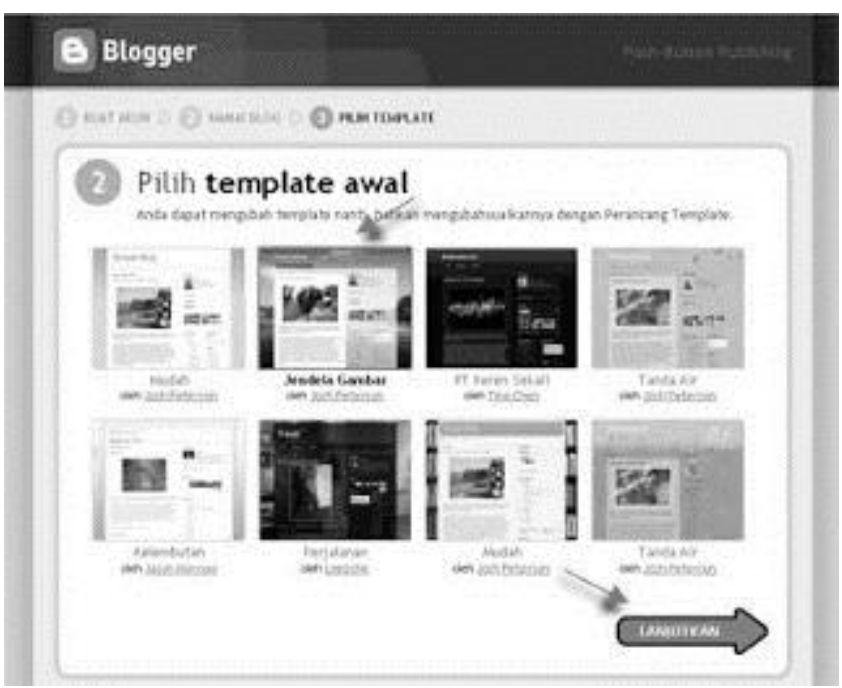

g. Akan ada tulisan "Blog Anda Sudah Jadi!". Silahkan lanjutkan dengan klik tombol MULAI BLOGGING.

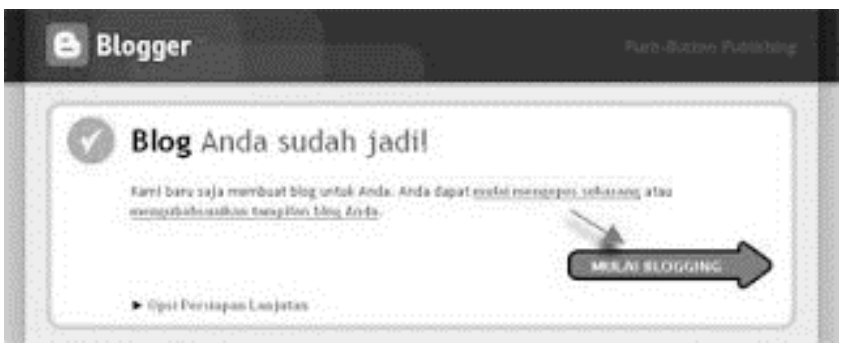


h. Setelah masuk post editor, silahkan isi apa saja ( disarankan untuk langsung mengisi posting, biasanya jika tidak langsung posting akan terjaring robot anti spam milik blogger, dan blog anda akan di lock). Contoh : hello world. Klik Tombol PRATINJAU untuk melihat tampilan yang nanti akan muncul di blog, klik tombol TERBITKAN ENTRI jika posting anda mau dipublikasikan ke publik.

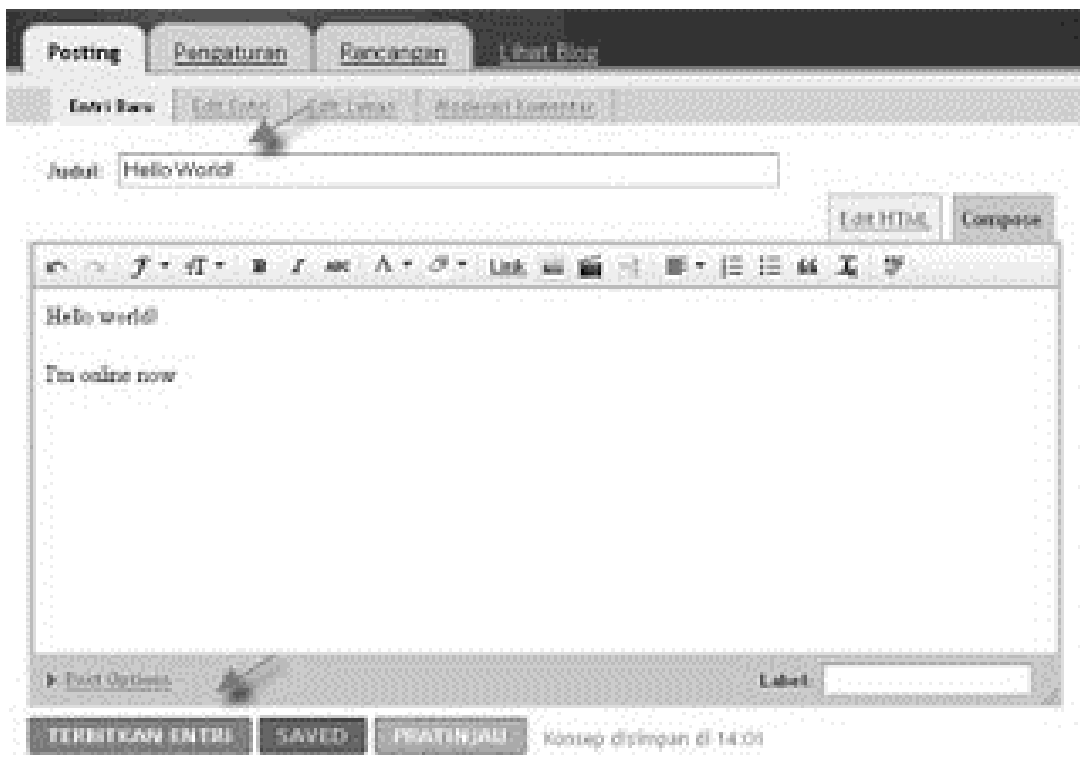

i.Klik "Lihat Entri" untuk melihat blog anda.

j.Selesai.

\section{Kesimpulan}

Dari paparan di atas maka, dapat diketahui bahwasanya media pembelajaran berbasis ICT/Multimedia merupakan gabungan dari media berbasis teknologi informasi dan media berbasis teknologi komunikasi dan bermuara pada media yang berbasis ICT/Multimedia. 
Salah satu media pembelajaran berbasis ICT adalah blog. Blog atau disebut juga dengan web log adalah sebuah aplikasi web yang berupa tulisan-tulisan ataupun gambar yang biasa disebut dengan sebuah posting atau postingan dalam sebuah halaman website umum seperti blog.

Dalam media pembelajaran berbasis ICT/Multimedia memilki data dan informasi yang merupakan komponen yang terpenting dalam sebuah media. Data adalah pesan-pesan pembelajaran yang belum diolah menjadi sebuah informasi yang sampaikan dalam proses pembelajaran. Sedangkan informasi adalah pesan-pesan yang sudah diolah, diorganisir dan siap untuk disalurkan kepada peserta didik dalam bentuk proses belajar mengajar.

Adapun manfaat dari media pembelajaran yaitu mampu mempermudah pendidik dalam mengajar di satu sisi, dan di sisi lain peserta didik mudah dalam menyerap, memahami, memaknai dan menelaah setiap materi ajar sehingga mampu direkonstruksi dan dinternalisasikan dalam kehidupan kongkritnya. 


\section{DAFTAR PUSTAKA}

Darmawan, Deni. 2012. Teknologi Pembelajaran. Bandung: PT Remaja Rosdakarya, 2012.

Mayer, Richard E. 2009. Multimedia Learning: Prinsip-Prinsip Dan Aplikasinya,. terj. Teguh Wahyu Utomo. Yogyakarta: Pustaka Pelajar.

Munadi, Yudhi. 2012. Media Pembelajaran. Sebuah Pendekatan Baru. Jakarta: Gaung Persada.

Munir, H. t.t. Kurikulum Berbasis TIK. Bandung: SPS Universitas Pendidikan Indonesia.

Munir. 2010. Kurikulum Berbasis Teknologi Informasi Dan Komunikasi. Bandung: Alfabeta.

Rusman,dkk. 2012. Pembelajaran Berbasis TIK. Jakarta: PT.Raja Grafindo Persada.

Sadiman, Arief S., dkk. 2007. Media Pendidikan. Jakarta: Rajawali.

Sudjana, Nana dan Ahmad Rivai. 2010. Media Pengajaran. Bandung: Sinar Baru Algensindo.

Sutopo, Ariesto Hadi. 2012. Teknologi Informasi Dan Komunikasi Dalam Pendidikan. Yogyakarta: Graha Ilmu.

Warsita, Bambang. 2008. Warsita, Tekhnologi Pembelajaran, Jakarta: PT. Rineka Cipta.

\section{Sumber Dari Internet}

http://www.ekocandra.zone/2011/07/pengertian-blog-fungsi-dankegunaannya.html 
http://nenenggeulis.blogspot.co.id/2015/05/pengembangan-mediapembelajaran.html

http://furqanwera.blogspot.com/2012/12/pemanfaatan-media-berbasisict-terhadap.html 